\title{
ENTREVISTA
}

\section{Entre a foice e o compasso: socialismo e maçonaria na trajetória de Eveardo Dias na Primeira República}

El investigador Michel Goulart da Silva ha defendido una Tesis de Doutorado, cuyo título es "Entre a foice e o compasso: socialismo e maçonaria na trajetória de Eveardo Dias na Primeira República" en la Universidade Federal de Santa Catarina en Brasil. Michel Goulart da Silva nació en 04 de setembro de 1983 en Florianópolis, no estado de Santa Catarina, no Brasil.

El autor ha concedido la siguiente entrevista.

\section{¿Cuáles fueron los motivos que le llevó a enfocar su investigación hacia la Masonería?}

Nos últimos anos, embora uma grande quantidade de pesquisadores acadêmicos tenha se dedicado a estudar a Maçonaria no Brasil, existem alguns temas que não foram explorados. Um desses temas é a relação da Maçonaria com o movimento operário e a inserção dos maçons em organizações de socialistas, anarquistas ou mesmo comunistas. A maioria dos pesquisadores acabou enfocando muito mais a participação de maçons em movimentos liderados por setores das oligarquias agrárias, em especial no século XIX. Nesse sentido, a escolha do imigrante espanhol Everardo Dias como objeto da minha pesquisa de doutorado foi muito importante, afinal, além de ser maçom, ele manteve relação com organizações e publicações anticlericais, socialistas e comunistas, ao longo das três primeiras décadas do século XX. Por meio do estudo de sua trajetória pública foi possível identificar parte da atuação dos maçons na imprensa e nas organizações do movimento operário nas primeiras décadas do século XX.

\section{¿Cuáles fueron las fuentes que ha utilizado?}

Foram utilizadas principalmente publicações operárias e anticlericais das primeiras décadas do século XX. O destaque foi o jornal anticlerical O Livre Pensador, editado por Everardo Dias, e a revista Clarté, de cujo grupo diretor Everardo Dias fazia parte. Ademais, foram fontes utilizadas na pesquisa as publicações de organizações anarquistas e sindicalistas revolucionárias, como os jornais Spártacus e A Plebe. Os livros escritos por Everardo Dias também foram fundamentais, em especial Semeando, em que reúne um conjunto de palestras proferidas por ele em lojas maçônicas, e Memórias de um exilado, em que narra a experiência de perseguição política e expulsão do Brasil, no final de 1919, e seu retorno, no 
começo de 1920.

\section{¿Cuáles fueron las principales dificultades con las que se ha encontrado? ¿Cómo las ha superado?}

Certamente a principal dificuldade foi a ausência de documentação que pudesse auxiliar a construir a trajetória maçônica de Everardo Dias. Em contato com a loja da qual fez parte, descobri que não havia arquivos do período, que os documentos relacionados a Everardo Dias teriam se perdido, por falta de uma política de preservação. Essa dificuldade foi sanada pelo uso da imprensa e de relatos escritos por próprio Everardo Dias ou por seus contemporâneos. O livro Semeando, em especial, permitiu, por meio das palestras realizadas em diferentes lojas, mapear parte da rede de relações maçônicas de Everardo Dias.

\section{¿Cuáles fueron las principales problemáticas históricas que su trabajo ha resuelto?}

Certamente a principal problemática da pesquisa era a relação entre maçons e militantes operários e de esquerda nas primeiras décadas do século. Mas por qual razão essa é uma problemática importante? Porque, no Brasil, a partir da década de 1930, a Maçonaria como instituição passa por um paulatino processo de adesão a posições conservadoras e anticomunistas, inclusive apoiando o golpe civil-militar de 1964. Para quem vê a Maçonaria contemporaneamente, seria estranho pensar que estiveram entre maçons muitos socialistas e até mesmo alguns fundadores do Partido Comunista, como é o caso de Everardo Dias. Por isso, a pesquisa partiu da hipótese de que havia uma cultura política republicana compartilhada por diferentes setores - maçons, socialistas, comunistas, anticlericais, anarquistas - que construía relações de afinidades eletivas entre eles, possibilitando sua colaboração em publicações e organizações.

\section{¿Por favor, podría resumir la esencia de su Tesis en dos líneas?}

Nas primeiras décadas do século XX, estabeleceram-se afinidades eletivas entre diferentes segmentos políticos e ideológicos, que tinham em comum uma perspectiva crítica em relação ao modelo republicano e compartilhavam uma mesma cultura política.

\section{¿Cuáles fueron las lecciones, a todos los niveles, personal y profesional, que usted ha deducido de su experiencia investigativa?}

Profissionalmente, colocar em prática uma pesquisa que, embora com os métodos da História, necessariamente incorporou elementos teóricos e até metodológicos de outros 
campos das Ciências Humanas, especialmente da Ciência Política e a Sociologia. Por mais estranho que pareça, essa aproximação entre diferentes áreas foi recebida com restrição por muitos interlocutores no campo da História.

\section{¿Ahora, cuáles son sus proyectos profesionales? \\ Devido aos fatos ocorridos recentemente na política brasileira, com a derrubada da presidente Dilma Rousseff por um grupo de parlamentares vinculados a esquemas de corrupção, com apoio do Poder Judiciário, estou iniciando pesquisa inserida no campo da História do Tempo Presente acerca das narrativas construídas pela imprensa ao longo desse processo político. Por meio desse projeto, a ser desenvolvido em estágio pós-doutoral que iniciarei em maio, pretendo discutir um conjunto de elementos que mostram a fragilidade da construção da experiência democrática no Brasil, depois do final da ditadura, e como esses elementos se articulam na ação de setores empresariais na derrubada da presidente reeleita em 2014.}

\section{¿Quisiera destacar algún aspecto que no se ha contemplado y que usted consideraría digno de reseñar?}

Em todo o processo da pesquisa foi de fundamental importância o diálogo com os pesquisadores que integram a rede da $R E H M L A C+$. Essa interlocução permitiu não apenas um aprofundamento teórico e metodológico, como muitas comparações com as experiências de pesquisa sobre Maçonaria de outros países, em especial a Espanha.

Esta entrevista se efectúo de forma telemática el 10 de março de 2016.

Autores de la entrevista: Ricardo Martínez Esquivel e Yván Pozuelo Andrés, director y editor de REHMLAC+.

DOI: http://dx.doi.org/10.15517/rehmlac.v9i1.28253 